\title{
Psychopharmacological Profile of Hydroalcoholic Extract and P-Hydroxybenzoic Acid Obtained from Bourreria huanita (Boraginaceae) in Mice
}

\author{
Iandra Holzmannn, ${ }^{2 *}$, Daiane Cattani1,2, Micheli Corso ${ }^{1,2}$, Daiane Perondi1,2, \\ Sabrina Zanella1,2, Cristiani Burger ${ }^{1,2}$, Luiz Carlos Klein Júnior ${ }^{1,2}$, Valdir Cechinel Filho',2, \\ Sully M. Cruz ${ }^{3}$, Miguel F. Torres ${ }^{3}$, Armando Cáceres ${ }^{3}$, Márcia Maria de Souza, ${ }^{1,2}$ \\ ${ }^{1}$ Programa de Pós-Graduação em Ciências Farmacêuticas, Universidade do Vale do Itajaí, Itajaí, Brazil \\ ${ }^{2}$ Núcleo de Investigações Químico Farmacêuticas, Universidade do Vale do Itajaí, Itajaí, Brazil \\ ${ }^{3}$ Facultad de CCQQ y Farmacia, Universidad de San Carlos, Guatemala City, Guatemala \\ Email: ${ }^{\text {iandrah@hotmail.com }}$
}

Received 31 July 2014; revised 30 August 2014; accepted 21 September 2014

Copyright (C) 2014 by authors and Scientific Research Publishing Inc.

This work is licensed under the Creative Commons Attribution International License (CC BY). http://creativecommons.org/licenses/by/4.0/

c) (i) Open Access

\section{Abstract}

Bourreria huanita (Lex.) Hemsl. (Boraginaceae) is a very rare and highly appreciated tree in Mesoamerica for its medicinal properties and beauty. It grows in a region extending from central Mexico to Costa Rica. Ethnobotanical surveys have shown that the infusion of dried flowers is popularly used as a tranquilizer to cure several diseases. In the present study we report the isolation of p-hydroxybenzoic acid (pHBZ) obtained from the hydroalcoholic extract (HE) of B. huanita, and the effect of both, the extract and the compound on the central nervous system in mice. HE of $B$. huanita $(100,150,300 \mathrm{mg} / \mathrm{kg})$ and $\mathrm{pHBZ}(10 \mathrm{mg} / \mathrm{kg})$ were orally administered to mice and $1 \mathrm{~h}$ later, behavioral tests were performed. The effects of HE and pHBZ were tested by pentylenetetrazole (PTZ) and strychnine (STR) induced seizures, pentobarbital-induced hypnosis, the forced swimming test and the tail suspension test, the elevated plus maze, apomorphine-induced stereotypy and the climbing test, the inhibitory avoidance test and the open-field test. $B$. huanita extract produced hypnotic, anxiolytic and antidepressant effects in animals, with no change in motor performance. On the other hand, the extract did not reduce PTZ and STR-induced convulsions, apomorphine-induced stereotypy or climbing. Moreover, no changes were observed in the animals' memory. The compound pHBZ was effective only in the depression tests. The results obtained in the present study suggest that $B$. huanita exhibited sedative, antidepressant and hypnotic activities in mice, and that the antidepressant activity may be mediated by an isolated compound identified as pHBZ.

\footnotetext{
*Corresponding author.
}

How to cite this paper: Holzmann, l., et al. (2014) Psychopharmacological Profile of Hydroalcoholic Extract and P-Hydroxybenzoic Acid Obtained from Bourreria huanita (Boraginaceae) in Mice. Pharmacology \& Pharmacy, 5, 983-995. 


\section{Keywords}

\section{Bourreria huanita, Antidepressant, Sedative and Hypnotic Activities, P-Hydroxybenzoic Acid}

\section{Introduction}

Bourreria huanita (Lex.) Hemsl. (Boraginaceae), is a very rare and highly appreciated tree in Mesoamerica for its medicinal properties, aroma and beauty. It grows in the region extending from central Mexico to Costa Rica [1]. The pollen of the flowers of this sacred tree has been found on the Rosalila Temple floor, and in a royal tomb of the Classical Period in Copan, Honduras, proving its use in ancestral rituals [2]. Today, it is known in Guatemala as "esquisúchil", a word derived from the ancient Náhuatl language of the Aztecs meaning "popcorn flower", due to the appearance of its fragrant white flowers. Because this tree was sacred to the native ethnic groups, it was planted in the XVI century in the gardens of certain churches, to attract the population to the Christian faith, but also as a recognized medicine. The most famous specimen in Guatemala was planted in the garden of The Calvary Church in Antigua Guatemala on March $19^{\text {th }}, 1657$, by the Christian Saint Hermano Pedro de Betancur. This sacred tree for the Guatemalans is still blooming profusely, in situ, after more than three centuries, which proves the longevity of this species, officially nearing extinction [3]. It is mentioned in the first medical book written in the Americas by the Aztec physician Martín De La Cruz in 1552 [4], who prescribes it for "the fatigue of whom administrates the republic and performs a public charge", suggesting a possible effect on the Nervous System.

Ethnobotanical surveys conducted in Guatemala have shown that the infusion of dried flowers is popularly used as a tranquilizer, to cure heart diseases and high blood pressure, as an analgesic, and as an antiseptic [5], mainly for skin complaints [6]. Pharmacological and phytochemical information about this plant is scarce. A recent study showed the absence of antifungal activity of the ethanolic extract of the flowers against Candida, Aspergillus and dermatophytes [7], but showed activity against subcutaneous fungi such as Fonsecaea pedrosoi and Sporothrix schenckii (MIC 12 - $25 \mu \mathrm{g} / \mathrm{ml}$ ) [8] while Calderon and co-workers [9] demonstrated anti-Leishmania mexicana activity displayed by the ethanolic extract of the leaf, but no activity against other protozoa. Phytochemical screening is still in progress but preliminary studies have shown the presence of flavonoids, coumarins, sesquiterpen lactones, saponins and essential oil [10]. One of the compounds isolated from the plant is p-hydroxybenzoic acid, which is commercially obtained. Considering the popular medicinal use of $B$. huanita against diseases affecting the central nervous system, the present study analyzed the therapeutic potential of the hydroalcoholic extract and the main isolated compound in different experimental models (sedative, hypnotic, etc.) in mice.

\section{Methods}

\subsection{Plant Material}

The plant was collected from Finca Belencito, Antigua Guatemala city, Guatemala (14³2'55.44"N, 9044'02.39"W), and shade-dried. A botanical sample was determined by Mario Veliz at the Herbarium of the School of Biology, USAC, and a voucher sample was deposited at the Farmaya Laboratory Herbarium (voucher \# CFEH 895).

\subsection{Extract Preparation}

Dried material was ground to a coarse grain, wet with $70 \%$ ethanol, and placed in a stainless steel percolator; $70 \%$ ethanol was added to obtain a tincture, which was concentrated in a rotary evaporator at controlled temperature to a syrupy consistency. Fresh ethanol was added for five consecutive days and the extract was concentrated [11]. Final drying was performed in a vacuum dryer with silica gel. The average yield of the extractable solids was $28.5 \%$.

\subsection{Isolation Procedure}

Firstly, $0.9 \mathrm{~g}$ of the hydroalcoholic extract of $B$. huanita was partitioned with hexane, ethyl acetate and butanol, giving $108 \mathrm{mg}, 312 \mathrm{mg}$ and $127 \mathrm{mg}$ of each fraction, respectively. The whole ethyl acetate fraction was submit- 
ted to chromatographic procedures over silica gel and eluted with hexane/dichloromethane/acetone/methanol (3:4:1.5:1.5), giving eight main fractions. From the second fraction, a precipitate was obtained, and cleaned with chloroform. This solid (22 mg) was identified by spectral data $\left(\mathrm{H}^{1}\right.$ - and $\left.{ }^{13} \mathrm{C}-\mathrm{NMR}\right)$ as p-hydroxybenzoic acid, in comparison with the literature data [12] and direct comparison with an authentic sample.

\subsection{Animals}

Non-fasted adult male Swiss mice (18 - 35 g) were used in the experiments. The animals were maintained in a temperature controlled environment $\left(22^{\circ} \mathrm{C} \pm 3^{\circ} \mathrm{C}\right)$, illuminated by daylight supplemented with electric light from 7:00 a.m. to 7:00 p.m., with free access to food and water. The experiments were performed after protocol approval by the Institutional Ethics Committee of UNIVALI (475/10) and were carried out in accordance with current guidelines for the care of laboratory animals and the ethical guidelines for investigations. The number of animals and intensity of the noxious stimuli used were the minimum necessary to demonstrate the consistent effects of the treatments.

\subsection{Drugs and Treatments}

The following drugs and reagents were used: vehicle (distilled water with $1 \mathrm{drop} / \mathrm{ml}$ of dimethylsulfoxide); diazepam (Cristália, Brazil) was used as reference drug (positive control) for anxiolytic, sedative, muscle relaxant activities; phenobarbital (Rhodia Farm, Brazil) was used as reference drug (positive control) for anticonvulsant activity; imipramine (Sigma, USA) was used as standard drug for an antidepressant effect; haloperidol (SIGMA, USA) and olanzaphine; Zypreza, Eli Lilly, São Paulo, Brazil) was used as standard drug for an antipsychotic effect; sodium pentobarbital (Aboott Labs., São Paulo, Brazil) was used for an hypnotic effect; strychnine and pentylenetetrazole (Sigma, USA) were used to induce convulsion respectively. B. huanita extract and p-hidroxybenzoic acid were dissolved in saline with $1 \mathrm{drop} / \mathrm{ml}$ of dimethylsulfoxide and administered p.o. All drugs used as positive controls were dissolved in saline with $1 \mathrm{drop} / \mathrm{ml}$ of dimethylsulfoxide and administered i.p. For the negative control, only saline with $1 \mathrm{drop} / \mathrm{ml}$ of dimethylsulfoxide was used, administered p.o. The volume of administration was $0.1 \mathrm{ml} / 10 \mathrm{~g}$ body weight. All the behavioral procedures were carried out between 8:00 and 12:00 a.m. in a temperature controlled room $\left(23^{\circ} \mathrm{C} \pm 1^{\circ} \mathrm{C}\right)$, illuminated with a $40 \mathrm{~W}$ red fluorescent bulb. Each animal was used only once. The doses of drugs used were selected based on experiments previously performed in our laboratory and on the literature data, and were previously reported not to affect locomotor activity [13]-[16].

\subsection{Sodium Pentobarbital-Induced Sleeping Time}

In order to evaluate the potentiation of hypnosis, sodium pentobarbital $(50 \mathrm{mg} / \mathrm{kg}$ ) was i.p.-injected to male mice one hour after oral administration of the B. huanita extract (100, 150 and $300 \mathrm{mg} / \mathrm{kg}$, p.o.) or pHBZ (10 mg/kg, p.o.). The latency and duration of hypnosis were recorded. Hypnosis time was measured by the loss of the righting reflex, the recovery of this reflex being considered as the hypnosis endpoint [17]. Diazepam (2.0 mg/kg, i.p.) was used as positive control.

\subsection{Elevated Plus-Maze}

The Elevated plus-maze (EPM) was used to evaluate the anxiolytic effects of the plant extract. Briefly, the apparatus comprised of two open arms $(25 \times 10 \mathrm{~cm})$ and two closed arms $(25 \times 10 \times 20 \mathrm{~cm})$ which extended outwards from a common central platform $(10 \mathrm{~cm} \times 10 \mathrm{~cm})$. The entire maze was elevated to a height of $90 \mathrm{~cm}$ above floor level. Mice received single oral administration of B. huanita extract (100, 150 and $300 \mathrm{mg} / \mathrm{kg}$, p.o.), pHBZ (10 mg/kg, p.o.) or vehicle and 60 min later, they were individually placed in the center of the EPM for 5 min [18]. The number of entries to the open and enclosed arms, and time spent in the open arms, were recorded. Entry into the arms was defined as the point when the animal places all four paws in the arm. Subsequently, the percentage of open arm entries $(100 \times$ open/total entries) and the percentage of time spent in the open arms (100 $\times$ open/open + enclosed) were calculated for each animal. Diazepam $(0.75 \mathrm{mg} / \mathrm{kg}$, i.p. $)$ was used as positive control [19].

\subsection{Step-Down Inhibitory Avoidance}

The inhibitory avoidance model (IAM) was used to assess the effects of the plant extract on the animals' mem- 
ory. The step-down apparatus consisted of an acrylic box $(12 \mathrm{~cm} \times 30 \mathrm{~cm} \times 15 \mathrm{~cm})$ whose floor consisted of parallel $1.0 \mathrm{~mm}$ diameter stainless steel bars spaced $1.0 \mathrm{~cm}$ apart. A $10 \mathrm{~cm}$-wide, $3.0 \mathrm{~cm}$-high, $6.0 \mathrm{~cm}$-long platform occupied the center of the grid floor. In the training session (day 1), immediately after stepping down and placing their paws on the grid, the animals received a $0.3 \mathrm{~mA} 2 \mathrm{~s}$ scrambled foot shock and were immediately withdrawn from the cage. The animals received the treatment with $B$. huanita extract $(100,150$ and $300 \mathrm{mg} / \mathrm{kg}$, p.o.) vehicle or $\mathrm{pHBZ}(10 \mathrm{mg} / \mathrm{kg}$, p.o.) immediately after the training session to investigate their effect on memory consolidation. Twenty-four hours later, in the test sessions (day 2), no foot shock was given and the stepdown latency was used as a measure of retention (to a ceiling of $300 \mathrm{~s}$ ) [20].

\subsection{Forced Swimming Test}

The forced swimming test (FST) is the most widely used pharmacological model for assessing antidepressant activity [21] [22]. The test was performed according to a modification of the traditional method described by Porsolt et al. [23]. The apparatus consisted of an opaque Plexiglas cylinder (50 cm high $\times 20 \mathrm{~cm}$ wide) filled with water at room temperature, to a depth of $30 \mathrm{~cm}$. B. huanita extract (100, 150 and $300 \mathrm{mg} / \mathrm{kg}$, p.o.), pHBZ (10 mg/kg, p.o.), vehicle (p.o.) or imipramine (20 mg/kg, i.p.) were administered 60 or 30 minutes prior to the swimming test. During the 6 min swimming test, immobility behavior was observed, defined as when the animal made no further attempts to escape except for the movements necessary to keep its head above the water. Reduction in immobility is considered as a behavioral profile consistent with an antidepressant-like action [15] [22].

\subsection{Tail Suspension Test}

The antidepressant effect of the plant extract and pHBZ was also evaluated by the tail suspension test (TST). The total duration of immobility induced by tail suspension was measured according to the method described by Steru et al. [24]. Briefly, mice isolated both acoustically and visually were suspended $50 \mathrm{~cm}$ above the floor by adhesive tape placed approximately $1 \mathrm{~cm}$ from the tip of the tail. Immobility time was recorded manually over a period of 6 min. Mice were considered immobile only when they hung passively or stayed completely motionless. Conventional antidepressants decrease the immobility time in this test. B. huanita extract (100, 150 and 300 $\mathrm{mg} / \mathrm{kg}$, p.o.), pHBZ (10 mg/kg, p.o.), saline (p.o.) or imipramine (20 mg/kg, i.p.) were administered 60 or 30 minutes prior to the tail suspension test.

In both depression experiments described above, the percentage decrease in immobility time (\%IM) for the test and standard drugs was calculated using the following formula:

$\% \mathrm{IM}=\left[\left(\mathrm{A} \_\mathrm{B}\right) / \mathrm{A}\right] \times 100$ Where $\mathrm{A}$ is the immobility time (s) in the control group and B is the immobility time (s) in the test group.

\subsection{Open Field Test}

To detect any association of immobility in the FST, IAM, TST with changes in motor activity, the activities of animals treated with the extract and the compound were tested in an open field test (OFT). The open-field arena consisted of acrylic (transparent walls and a black floor, $30 \times 30 \times 15 \mathrm{~cm}$ ), divided into nine squares of equal areas. The animals received the extract of $B$. huanita (100 - $300 \mathrm{mg} / \mathrm{kg}$, p.o.), pHBZ (10 mg/kg p.o.) and haloperidol (2.5 mg/kg, i.p.) 60 or $30 \mathrm{~min}$ prior test. The mice was placed individually in the center of the arena, and allowed to explore it freely. The parameters observed were: ambulation or crossing (the number of squares crossed with all four paws) and number of rearings, both recorded for the last 5 min of the 6 min testing period.

\subsection{Pentylenetrazole (PTZ) and Strychinine (STR)-Induced Seizures}

Seizures were induced chemically with PTZ and STR as described by Tolardo et al. [13] with minor modifications. Groups of 8 - 10 mice were treated with the B. huanita extract (100, 150 and $300 \mathrm{mg} / \mathrm{kg}$, p.o.), pHBZ (10 $\mathrm{mg} / \mathrm{kg}$ p.o.), phenobarbital (40 mg/kg, i.p.) or vehicle, and 30 or $60 \mathrm{~min}$ afterwards, received a convulsant dose of PTZ (100 mg/kg, i.p.) or STR (4.0 mg/kg, i.p.). Immediately after treatment with convulsant agents, the animals were placed individually in cages and observed for the next $60 \mathrm{~min}$. The time to onset of seizures and the mortality rates were recorded during this time. 


\subsection{Apomorphine-Induced Stereotypy and Climbing}

Mice were isolated in wire-mesh cages for $30 \mathrm{~min}$ and then treated with $B$. huanita extract (100, 150 and 300 $\mathrm{mg} / \mathrm{kg}$, p.o.), olanzaphine (10 mg/kg, i.p.) or vehicle. After $30 \mathrm{~min}$, they were injected with apomorphine (1 $\mathrm{mg} / \mathrm{kg}$, s.c.) and observed for $90 \mathrm{~min}$ at $10 \mathrm{~min}$ intervals for signs of stereotypy based on the following scale: 0 (asleep or stationary), 1 (active), 2 (active with predominantly stereotyped sniffing and rearing), 3 (stereotyped sniffing with bursts of licking and/or gnawing and biting), 4 (continual licking and/or gnawing of the cage mesh) [25]. In the same mice, climbing behavior was also assessed for $90 \mathrm{~min}$ at 10 minutes intervals according to the following scale: 0 (no climbing), 1 (climbing with two forepaws only), 2 (climbing with four paws); [26] [27]. Total scores were calculated by summing the scores recorded for each 10 min interval.

\subsection{Statistical Analysis}

The total apomorphine-induced stereotypy scores, climbing scores, catalepsy (with vehicle pretreatment), and locomotor activity data were analyzed by one-way analysis of variance (ANOVA), with treatment as a factor, followed by the Newman-Keuls test. For the statistical analysis of non-parametric data from the IA test, the Mann-Whitney U-test was used. Data were analyzed by NCSS and Graph pad INSTAT® version 4.0 software and presented as mean \pm S.E.M. values (except for models of stereotypy and climbing). The statistical tests used were one-way analysis of variance (ANOVA) followed by Newman-Keuls's post hoc test. A probability level of 0.05 or less was accepted as significant.

\section{Results}

\subsection{Sodium Pentobarbital-Induced Sleeping Time}

Figure 1 shows the effects of the HE (100 - $300 \mathrm{mg} / \mathrm{kg})$, pHBZ (10 mg/kg) and diazepam (2.0 mg/kg) on pentobarbital-induced sleep in mice. Only treatment with the extract at a dose of $300 \mathrm{mg} / \mathrm{kg}$, and diazepam was effective in prolonging pentobarbital-induced sleeping time $(\mathrm{HE} \mathrm{F} \mathrm{(5.50)} \mathrm{=} \mathrm{9.64,} \mathrm{p} \mathrm{<} \mathrm{0.05;} \mathrm{DZP} \mathrm{F} \mathrm{(5.50)} \mathrm{=} \mathrm{9.64,} \mathrm{p}$ $<0.001)$.

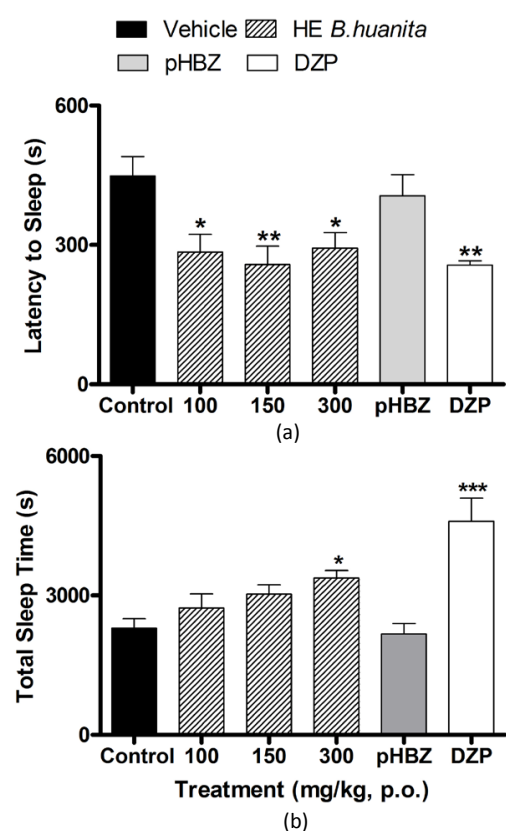

Figure 1. Effect of acute administration of HE of B. huanita (50, 100 and $150 \mathrm{mg} / \mathrm{kg}$, p.o.) pHBZ (10 mg/kg, p.o.) and diazepam (2.0 mg/kg, i.p.) on (a) time latency for sleep and (b) total time of sleep induced by pentobarbital sodium (50 mg/kg, i.p.). The treatments or negative control (Veh, $10 \mathrm{~mL} / \mathrm{kg}$, p.o.), but not diazepam, were administered $1 \mathrm{~h}$ prior to pentobarbital administration. The latency and duration of hypnosis were recorded for up to 2 hours. No hypnotic effect was observed with treatment of animals with the compound pHBZ. The data are reported as means \pm SEM. $\mathrm{N}=8-10$ mice ${ }^{*} \mathrm{p}<0.05$, ${ }^{* *} \mathrm{p}<$ 0.01 and ${ }^{* * *} \mathrm{p}<0.001$ compared to the control group (ANOVA followed by the Student-Newmann-Keuls analysis). 


\subsection{Elevated Plus-Maze}

The number of entries into the open arms $(\mathrm{F}(4.34)=8.54, \mathrm{p}<0.05, \mathrm{p}<0.001)$ Figure 2(a) was increased in a dose dependent manner by p.o. treatment with $\mathrm{HE}$ of $B$. huanita $(100-300 \mathrm{mg} / \mathrm{kg})$ and i.p. treatment with diazepam $(0.75 \mathrm{mg} / \mathrm{kg})$, when compared to control animals treated with vehicle. In addition, the time spent in the open arms $(F(4.31)=25.96, p<0.001)$ Figure $2(b)$ was increased by diazepam and HE of this plant at all the doses tested. No statistical differences were observed for treatments in relation the entry of animals into the closed arms (data not shown). It was also observed that treatment of animals with $\mathrm{pHBZ}$ was not able to change the behavioral parameters observed in the plus maze $(\mathrm{p}>0.05)$.

\subsection{Forced Swimming and Tail Suspension Tests}

One-way ANOVA $(\mathrm{F}(5.46)=16.67)$ showed that oral and acute treatment with HE of $B$. huanita significantly reduced immobility time at doses of $100 \mathrm{mg} / \mathrm{kg}(\mathrm{p}<0.01), 150 \mathrm{mg} / \mathrm{kg}(\mathrm{p}<0.01)$, and $300 \mathrm{mg} / \mathrm{kg}(\mathrm{p}<0.001)$ compared with saline-treated control mice Figure 3(a). The positive control imipramine and pHBZ decreased immobility time in the FST at a dose of $20 \mathrm{mg} / \mathrm{kg}$ and $10 \mathrm{mg} / \mathrm{kg}$ respectively $(\mathrm{p}<0.001)$ Figure 3(a). One-way ANOVA of the TST data Figure 3(b) revealed that HE treatment at doses of $150 \mathrm{mg} / \mathrm{kg}(\mathrm{p}<0.01)$ and 300 $\mathrm{mg} / \mathrm{kg}(\mathrm{p}<0.001)$ significantly reduced immobility time, but $100 \mathrm{mg} / \mathrm{kg}$ dose had no effects $(\mathrm{p}>0.05)$ on immobility compared with vehicle-treated control mice. It was also observed that the positive control imipramine $(20 \mathrm{mg} / \mathrm{kg}$ ) and pHBZ $(10 \mathrm{mg} / \mathrm{kg})$ significantly reduced immobility time in the TST ( $\mathrm{p}<0.001)$, compared with control mice.

\subsection{Measuring Locomotor Activity: Open Field Test}

B. huanita extract at doses of 100, 150 and $300 \mathrm{mg} / \mathrm{kg}$ and pHBZ (10 mg/kg), did not show any changes in motor activity in mice, as assessed by the OFT Figure 4. Significant effects was detected only with haloperidol, used as positive control, which produced a significant decrease in both parameters (crossings and rearings) $(\mathrm{F}(5.52)=34.32, \mathrm{p}<0.0001)$.

\subsection{Pentylenetetrazole and Strychinine-Induced Seizures}

Comparison between the treatment of animals with HE of B. huanita (100 - 150 and $300 \mathrm{mg} / \mathrm{kg}$ ), pHBZ (10 $\mathrm{mg} / \mathrm{kg}$ ), phenobarbital (40 mg/kg) and the control group showed that only phenobarbital significantly suppressed STR- and PTZ-induced clonic seizures, with complete suppression $(F(5.51)=7.20 ; F(5.47)=21.22)$, and was also able to protect against 24-hour lethality (results not shown).

\subsection{Apomorphine-Induced Stereotypy and Climbing}

Olanzaphine (10 mg/kg) blocked apomorphine-induced stereotypy Figure 5(a). The total stereotypy score was reduced by olanzaphine $(\mathrm{F}(7.59)=122.71, \mathrm{p}<0.001)$; Figure 5(a). Apomorphine-induced stereotypy was not blocked by treatment of animals with HE of B. huanita at the doses tested. At the doses tested, HE of $B$. huanita alone did not induce stereotypy. Olanzaphine (but not HE of $B$. huanita) inhibited the total score of apomorphine-induced climbing $(F(7.58)=6.89, \mathrm{p}>0.001)$ Figure $5(\mathrm{~b})$.

\subsection{Step-Down Inhibitory Avoidance}

Finally, B. huanita extract does not alter the memory retention in the animals treated in the inhibitory avoidance test, at any of the doses used (Figure 6).

\section{Discussion}

In this study, the general depressant activity of B. huanita extract was confirmed by a decrease in sleep latency and an increase in pentobarbital-induced sleeping time, which may be attributed to an inhibition of the pentobarbital metabolism or to an action in the regulation of sleep [22]. In addition to the lack of any observed effect of $B$. huanita extract in the animals submitted to the open field test, it also exhibited general depressant activity, but did not interfere with the animals' motor system. The hypnotic action of pentobarbital was demonstrated by 


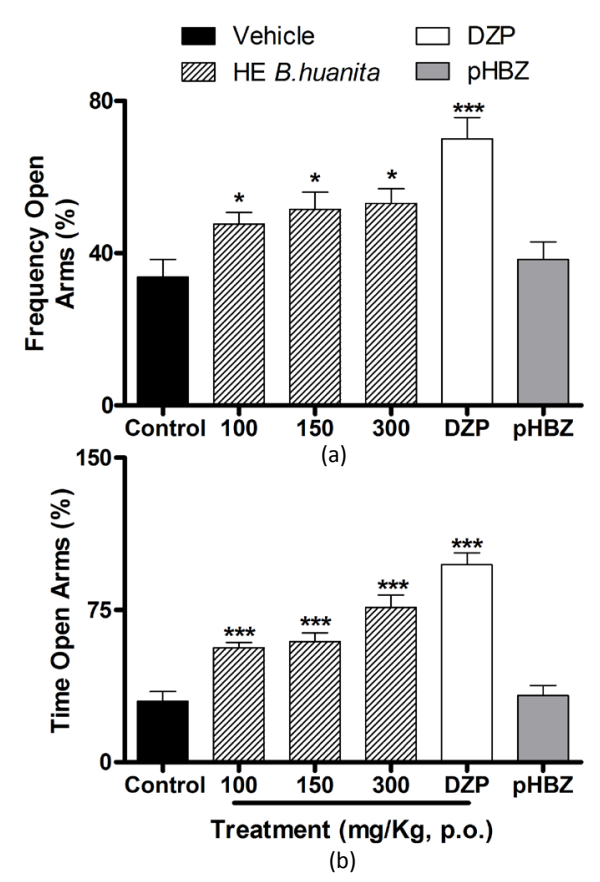

Figure 2. Effects of acute administration of HE of B. huanita (50, 100 and $150 \mathrm{mg} / \mathrm{kg}, \mathrm{p.o.}$ ) pHBZ (10 mg/kg, p.o.) and diazepam ( $0.75 \mathrm{mg} / \mathrm{kg}$, i.p.) in the elevated plus maze test, in mice. The treatments or negative control (Veh, $10 \mathrm{~mL} / \mathrm{kg}$, p.o.) were administered $1 \mathrm{~h}$ prior to the test, and during the 5 minute test, the following were measured: (a) = number of entries into the open arms, (b) = time spent in the open arms. Anxiolytic effect was not observed with treatment of animals with the compound pHBZ. Each bar represents the mean \pm SEM of 8 to 10 animals per group ${ }^{*} \mathrm{p}<0.05,{ }^{* *} \mathrm{p}<0.01$, compared with the corresponding control value. The data were analyzed by the ANOVA or t-test and complemented by the Newman-Keuls post-hoc test.
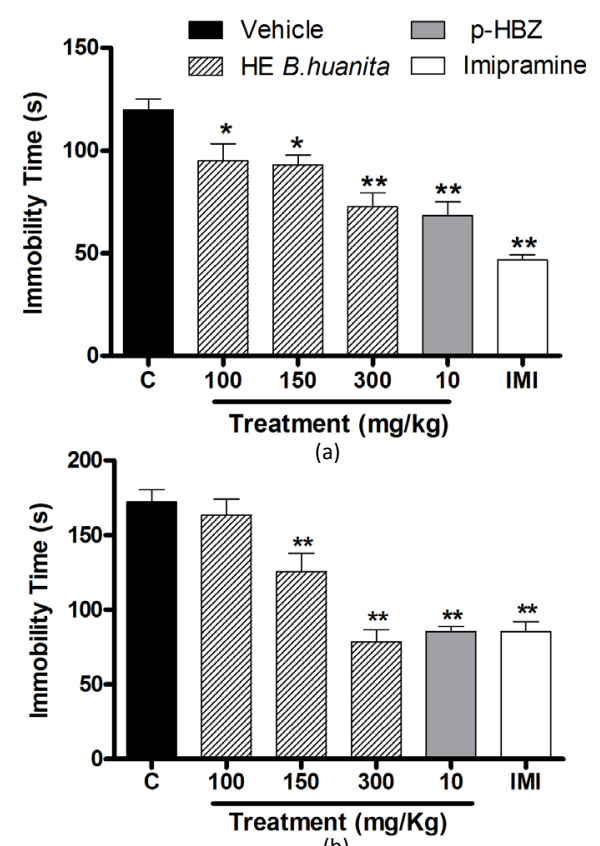

(b)

Figure 3. Effect of HE of B. huanita (50, 100 and $150 \mathrm{mg} / \mathrm{kg}$, p.o.), p-hydroxybenzoic acid pHBZ (10 mg/kg) and imipramine (10 mg/kg, i.p.) administered acute on the immobility time in mice in (a) Forced Swimming and (b) Suspension Tests. In both tests, the treatments were carried out $1 \mathrm{~h}$ beforehand, and during the 6 minute test, the immobility time of the animals was evaluated. The data are reported as means \pm SEM. $\mathrm{N}=8-10$ mice. ${ }^{*} \mathrm{p}<0.01,{ }^{* *} \mathrm{p}<0.01$ compared to the control group (ANOVA followed by Student-Newmann-Keuls analysis). 

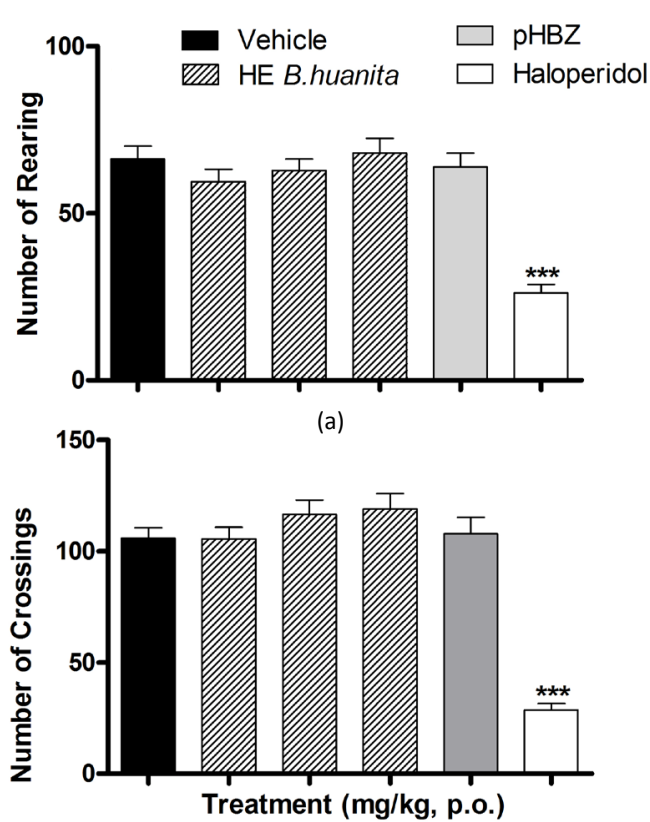

(b)

Figure 4. Effects of acute administration of HE B. huanita (100, 150 and $300 \mathrm{mg} / \mathrm{kg}$, p.o.), pHBZ (10 mg/kg, p.o.) or haloperidol (2 mg/kg, p.o) on behavioral parameters of mice evaluated in the open field test. The treatments or negative control (Veh, $10 \mathrm{~mL} / \mathrm{kg}$, p.o.) were administered $1 \mathrm{~h}$ prior to test, and during the 6 minute test, the following were measured: (a) = number of crossings and (b) = number of rearings. Each bar represents the mean \pm SEM of 6 to 10 animals per group. ${ }^{* * *} \mathrm{p}<$ 0.001 , compared with the corresponding control value. The data were analyzed by ANOVA or t-test and complemented by the Newman-Keuls post-hoc test.
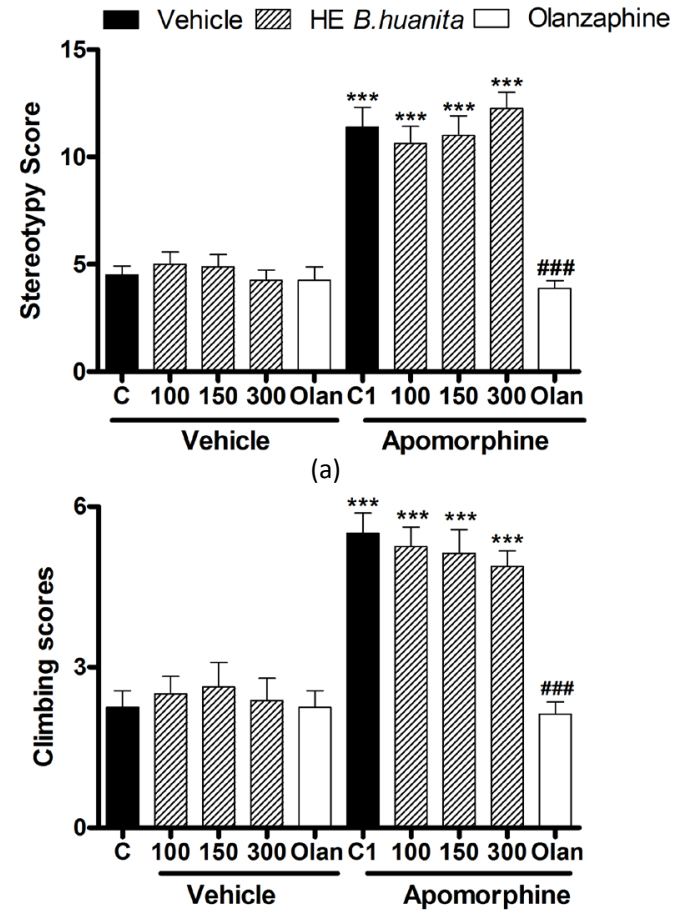

(b)

Figure 5. Effects of acute administration of HE B. huanita (100, 150 and $300 \mathrm{mg} / \mathrm{kg}, \mathrm{p} .0)$ and olanzaphine (10 mg/kg, i.p.) on (a) apomorphine induced stereotypy scores and (b) apomorphine-induced climbing scores. The data are expressed as mean + SEM ( $n=7-10$ per group). The asterisks denote the levels of significance ${ }^{* * *} \mathrm{p}<0.001$, compared with control (vehicle + vehicle); ${ }^{\# \# \# ~} \mathrm{p}<0.001$, compared with apomorphine + vehicle. 


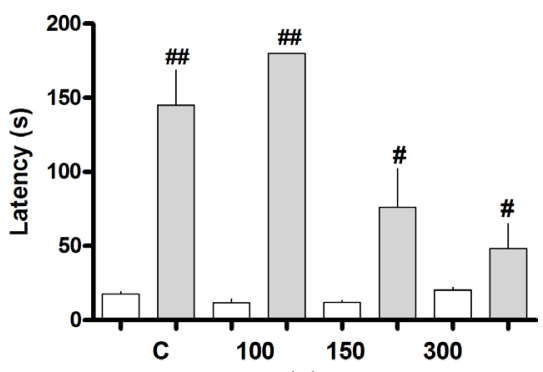

(a)

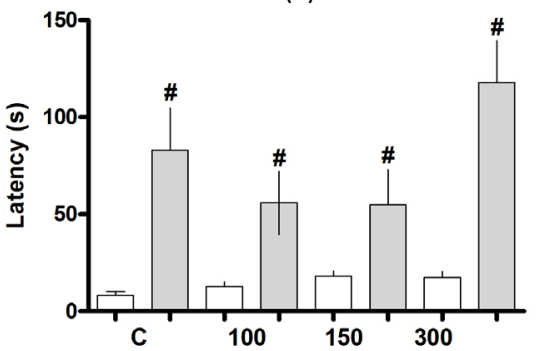

(b)

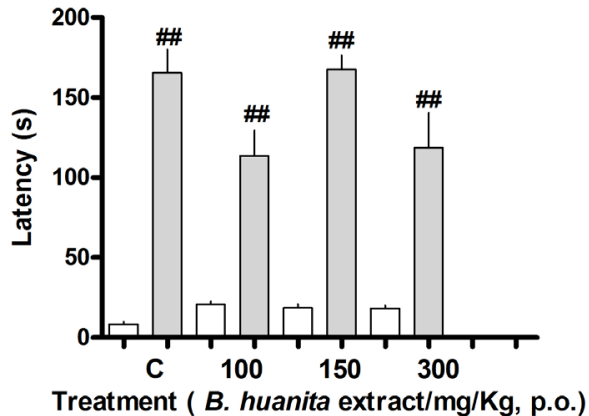

(c)

Figure 6. Effect of acute administration of HE from B. huanita (100, 150 e $300 \mathrm{mg} / \mathrm{kg}$, p.o) on the (a) acquisition (b) consolidation and (c) retrieval of memory available in the inhibitory avoidance test. Treatments were performed $1 \mathrm{~h}$ before and after the training session to assess the acquisition and consolidation of memory, respectively, and $1 \mathrm{~h}$ before the test session to evaluate retrieval of memory. Each bar represents the median (interquartile range) of 8 to 10 animals per group. The white bars represent the training sessions and the gray bars represent the test sessions. There were no statistical differences between the training and testing in each group, but not were differences between treatments compared to the control (C/vehicle) in the test session. The symbols denote the significance levels \# $(\mathrm{p}<0.05)$, \#\# $(\mathrm{p}<0.01)$ comparisons between the training and test sessions. The data were analyzed by ANOVA and complemented by the Kruskal-Wallis or Mann-Whitney U tests.

Petty [28] to be mediated by the $\mathrm{GABA}_{\mathrm{A}}$ receptor complex. The EPM test was used to study the possible anxiolytic effect of $B$. huanita extract. Anxiety, a symptom that accompanies various central nervous system disorders, and is also a disorder in itself, is characterized in humans by a tense and exhaustive physical alertness. Other animal species display a variety of defensive reactions in response to predators, some of which are understood as correlated states of anxiety [29]. Rodents demonstrate aversion, fear and curiosity when placed in a new environment, and an overall assessment of behavior can be determined through the observation of freezing, grooming (fear) or rearing, head-dips (curiosity) and the number of fecal boluses produced. EPM has frequently been used to detect and evaluate the anxiolytic/anxiogenic properties of drugs [30]. The frequency and time spent in the open arms is the main indicator of fear in the EPM, given that an open area is extremely aversive to rodents [31]. In addition, in the open arms, there is no thigmotaxis [32], which enhances the state of fear and aversion in the animals. This animal model is sensitive to anxiolytics like benzodiazepines, which are generally used as positive control in experiments with EPM [33]. Our results showed that $B$. huanita extract was also able to significantly increase the time spent, as well as the number of entrances to the open arms, indicating a positive re- 
sponse in this test. The results may also suggest that the anxiolytic effect observed in animals treated with $B$. huanita extract may be mediated by the GABAergic system. Substances with anxiolytic effects, such as the benzodiazepines, which promote anterograde amnesia, may induce cognitive deficits [34]. We therefore investigated the effects of the $B$. huanita extract and the isolated compound on memory in mice, separately evaluating the acquisition phase, consolidation and recall. With this aim, we used the inhibitory avoidance test, which assesses the animals' emotional memory [35]. In this study, there were no effects on memory in mice. Therefore, the use of the plant as an anxiolytic does not interfere in memory.

The FST and TST are used to detect and characterize the efficacy of antidepressant drugs, and are sensitive to these drugs after acute administration [36]. They are also an important tool for studying the neurobiological mechanisms involved in antidepressant activities [37]. Nowadays, antidepressants are known to act by several distinct mechanisms at the receptor level, reuptake of neurotransmitters, inhibition enzymes which are involved in the metabolism of neurotransmitters and probably also stimulating similar pathways at the sub-cellular level [38]. Several authors have proposed that immobility during the test could be an efficient adaptive response to this stress [37]. In this study, treatment of the animals both with B. huanita extract and with pHBZ were able to decrease the immobility time in both models of depression, suggesting an antidepressant behavior in response to an inescapable source of stress.

Schizophrenia is a disorder characterized by changes in behavior, emotion, perception and cognition. The latter include impairments in working, memory, planning and judgment and attention. The etiology of disease appears to be multifactorial, caused by genetic alterations and environmental factors, and has also been linked to increased dopaminergic neurotransmission [39] [40]. Stereotyped behavior is one of the prominent features of psychotic symptoms; it manifests as repetitive performance of strange gestures [41]. Apomorphine-induced stereotypy is an animal model that is classically linked to motor agitation, one of the positive symptoms of schizophrenia, and can be altered by substances that induce motor deficits. The drug activates post-synaptic dopamine D2 receptors in the brain, increases locomotor activity, and produces characteristic stereotyped behavior, which consists of persistent sniffing, gnawing, intense licking and chewing in control animals. Antagonism of apomorphine indicates neuroleptic activity. In apomorphine-induced stereotypic behavior in mice, $B$. huanita extract did not reduce the intensity of apomorphine-induced stereotypic behavior. However, olanzaphine blocked apomorphine-induced stereotypy. These data corroborate with the fact that striatal D2 blockade is correlated with improvements in positive symptoms in schizophrenia patients [42], and stereotypy induced by dopamine agonists is related to D2 receptor activation in the striatum [43]. The inability of B. huanita to block apomorphine suggests that there is no interference with central dopaminergic neurotransmission. Furthermore, these results confirm the findings obtained with animals treated with the plant extract and analyzed in the open field.

In the search for the active substances of $B$. huanita, some compounds have been detected, but not yet identified, including flavonoides, coumarins, sesquiterpene lactones, saponins and essential oil [10], but it is still uncertain which of these is responsible for the effects observed. In this study, we have isolated a compound, identified as p-hydroxybenzoic acid, which was evaluated in some pharmacological models, but it demonstrated only antidepressant effects. There is no reference in the literature on possible effects of the compound on the CNS, and it appears that this is not the only compound responsible for all the effects of the plant studied here.

\section{Conclusion}

The results obtained in the present study suggest that $B$. huanita exhibits sedative, antidepressant and hypnotic activities in mice, and that the antidepressant activity can be mediated by the isolated compound. Further studies are being conducted to assess whether the plant exhibits toxicological effects.

\section{Conflicts of Interest}

The authors declare that there are no conflicts of interest.

\section{Acknowledgements}

The authors are grateful to Prof. Mario Veliz for the botanical classification. This study was supported by grants from the Conselho Nacional de Desenvolvimento Científico e Tecnológico (CNPq), FAPESC, Ribiofar/CYTED and UNIVALI, Brazil. 


\section{References}

[1] Standley, P.C. and Williams, L.O. (1965) Flora of Guatemala. Fieldiana: Botany, 114, 24-29. http://dx.doi.org/10.1086/404579

[2] McNeil, C.L. (2003) Paleobotanical Research at Copán, Honduras. Foundation for the Advancement of Mesoamerican Studies, Inc. (FAMSI), Crystal River, Fla.

[3] Delgado, J.F., Torres, M.F., Pérez, P.P., Sánchez, R. and Rodríguez, O. (2009) The Two Worlds of Hermano Pedro (Tenerife-Guatemala). Litografía Romero, S.L., Tenerife, Islas Canarias.

[4] De la Cruz, M. (1964) Libellus de Medicina libus Indorum Herbis. Instituto Mexicano del Seguro Social, México.

[5] Torres, M.F. (2009) El Tesoro de El Calvario Patrimonio de La Antigua Guatemala. Fundación G\&T Continental, Guatemala.

[6] Orellana, S.L. (1989) Indian Medicine in Highland Guatemala: The Pre-Hispanic and Colonial Periods. Ethnohistory, 36, 338. http://dx.doi.org/10.2307/482693

[7] Svetaz, L., Zuljan, F., Derita, M., Petenatti, E., Tamayo, G., Cáceres, A., Cechinel-Filho, V., Giménez, A., Pinzón, R., Zacchino, S.A. and Gupta, M. (2010) Value of the Ethnomedical Information for the Discovery of Plants with Antifungal Properties. A Survey among Seven Latin American Countries. Journal of Ethnopharmacology, 127, 137-158. http://dx.doi.org/10.1016/j.jep.2009.09.034

[8] Gaitán, I., Paz, A.M., Zacchino, S.A., Tamayo, G., Giménez, A., Pinzón, R., Cáceres, A. and Gupta, M.P. (2011) Subcutaneous Antifungal Screening of Latin American Plant Extracts against Sporothrix schenkii and Fonsecaea pedrosoi. Pharmaceutical Biology, 49, 907-919. http://dx.doi.org/10.3109/13880209.2011.555916

[9] Calderon, A., Romero, L.I., Ortega-Barría, E., Solis, P.N., Zacchino, S., Gimenez, A., Pinzon, R., Caceres, A., Tamayo, G., Guerra, C., Espinosa, A., Correa, M. and Gupta, M.P. (2010) Screening of Latin American Plants for Antiparasitic Activities against Malaria, Chagas Disease, and Leishmaniasis. Pharmaceutical Biology, 48, 545-553. http://dx.doi.org/10.3109/13880200903193344

[10] Cruz, S.M., García, E.P., Letrán, H., Gaitán, I., Medinilla, B., Paredes, M.E., Orozco, R., Samayoa, M.C. and Cáceres, A. (2008) Caracterización química y evaluación de la actividad biológica de Bourreria huanita (Llave \& Lex.) Hemsl. (Esquisuchil) y Litsea guatemalensis Mez. (Laurel). Informe Final del Proyecto, Dirección General de Investigación, Universidad de San Carlos, Guatemala.

[11] Sharapin, N. (2000) Fundamentos de Tecnología de Productos Fitoterapéuticos. Convenio Andres Bello y CYTED, Bogotá.

[12] Peungvicha, P., Temsiririrkkul, R., Praisan, J.K., Tezuca, Y., Kadota, S., Thirawarapan, S.S. and Watanabe, H. (1998) 4-Hydroxybenzoic Acid: A Hypoglycemic Constituent of Aqueous Extract of Pandanus odorus Roots. Journal of Ethnopharmacology, 62, 79-84. http://dx.doi.org/10.1016/S0378-8741(98)00061-0

[13] Tolardo, R., Zetterman, L., Bittencourtt, D.R., Mora, T.C., de Oliveira, F.L., Biavatti, M.W., Amoah, S.K., Bürger, C. and de Souza, M.M. (2010) Evaluation of Behavioral and Pharmacological Effects of Hedyosmum brasiliense and Isolated Sesquiterpene Lactones in Rodents. Journal of Ethnopharmacology, 128, 63-70. http://dx.doi.org/10.1016/j.jep.2009.12.026

[14] O’Neill, M.F. and Conway, M.W. (2001) Role of 5-HT $\mathrm{HA}_{1 \mathrm{~A}}$ and 5-HT $\mathrm{HB}_{1 \mathrm{~B}}$ Receptors in the Mediation of Behavior in the Forced Swim Test in Mice. Neuropsychopharmacology, 24, 391-398. http://dx.doi.org/10.1016/S0893-133X(00)00196-2

[15] Jesse, C.R., Wilhelm, E.A., Bortolatto, C.F. and Nogueira, C.W. (2010) Evidence for the Involvement of the Serotonergic 5- $\mathrm{HT}_{2 \mathrm{~A} / \mathrm{C}}$ and $5-\mathrm{HT}_{3}$ Receptors in the Antidepressant-Like Effect Caused by Oral Administration of Bis Selenide in Mice. Progress in Neuro-Psychopharmacology and Biological Psychiatry, 34, 294-302. http://dx.doi.org/10.1016/j.pnpbp.2009.11.023

[16] Zomkowski, A.D.E., Rosa, A.O., Lin, J., Santos, A.R., Calixto, J.B. and Rodrigues, A.L.S. (2004) Evidence for Serotonin Receptor Subtypes Involvement in Agmatine Antidepressant Like-Effect in the Mouse Forced Swimming Test. Brain Research, 1023, 253-263. http://dx.doi.org/10.1016/j.brainres.2004.07.041

[17] Carlini, E.A., Contar, J.D.P., Silva-Filho, A.R., da Silveira-Filho, N.G., Frochtengarten, M.L. and Bueno, O.F. (1986) Pharmacology of Lemongrass (Cymbopogon citratus Stapf.). I. Effects of Teas Prepared from the Leaves on Laboratory Animals. Journal of Ethnopharmacology, 17, 37-64. http://dx.doi.org/10.1016/0378-8741(86)90072-3

[18] Pellow, S. and File, S.E. (1987) New Adaptations in Plus-Maze Labyrinth. Pharmacology Biochemistry and Behavior, 24, 520-525.

[19] De Souza, M.M., Bella-Cruz, A., Schumacher, M.B., Kreuger, M.R.O., Freitas, R.A. and Cruz, R.C.B. (2003) Métodos de Avaliação de Atividade Biológica de Produtos Naturais e Sintéticos. In: Bresolin, T.M.B. and Cechinel Filho, V. Eds., Ciências Farmacêuticas: Contribuição ao desenvolvimento de Novos Fármacos e Medicamentos, Univali, Itajaí, 
109-168.

[20] Izquierdo, I., Cammarota, M., Medina, J.H. and Bevilaqua, L.R. (2004) Pharmacological Findings on the Biochemical Bases of Memory Processes: A General View. Neural Plasticity, 11, 159-189. http://dx.doi.org/10.1155/NP.2004.159

[21] Brocardo, P.S., Budni, J., Kaster, M.P., Santos, A.R.S. and Rodrigues, A.L.S. (2008) Folic Acid Administration Produces an Antidepressant-Like Effect in Mice: Evidence for the Involvement of the Serotonergic and Noradrenergic Systems. Neuropharmacology, 54, 464-473. http://dx.doi.org/10.1016/j.neuropharm.2007.10.016

[22] Holzmann, I., Filho, V.C., Mora, T.C., Cáceres, A., Martínez, J.V., Cruz, S.M. and Souza, M.M. (2011) Evaluation of Behavioral and Pharmacological Effects of Hydroalcoholic Extract of Valeriana prionophylla Standl. from Guatemala. Evidence-Based Complementary and Alternative Medicine, 2011, Article ID: 312320. http://dx.doi.org/10.1155/2011/312320

[23] Porsolt, R.D., Le Pinchon, M., Jalfre, M. and Chatterjee, S.S. (1977) Depression: A New Animal Model Sensitive to Antidepressant Treatments. Nature, 266, 730-732. http://dx.doi.org/10.1038/266730a0

[24] Steru, L., Chermat, R., Thierry, B. and Simon, P. (1985) The Tail Suspension Test: A New Method for Screening Antidepressants in Mice. Psychopharmacology, 85, 367-370. http://dx.doi.org/10.1007/bf00428203

[25] Chinen, C.C., Faria, R.R. and Frussa-Filho, R. (2006) Characterization of the Rapid-Onset Type of Behavioral Sensitization to Amphetamine in Mice: Role of Drug-Environment Conditioning. Neuropsychopharmacology, 31, 151-159. http://dx.doi.org/10.1038/sj.npp.1300789

[26] Marcais, J., Protais, P., Costentin, J. and Schwartz, J.C. (1978) A Gradual Score to Evaluate the Climbing Behaviour Elicited by Apomorphine in Mice. Psychopharmacology, 56, 233-234. http://dx.doi.org/10.1007/BF00431856

[27] Protais, P., Costentin, J. and Schwartz, J.C. (1976) Climbing Behaviour Induced by Apomorphine in Mice: A Simple Test for the Study of Dopamine Receptors in Striatum. Psychopharmacology, 50, 1-6. http://dx.doi.org/10.1007/BF00634146

[28] Petty, F. (1995) GABA and Mood Disorders: A Brief Review and Hypothesis. Journal of Affective Disorders, 34, 275281. http://dx.doi.org/10.1016/0165-0327(95)00025-I

[29] Jackson, M.J. and Turkington, D. (2005) Depression and Anxiety in Epilepsy. Journal of Neurology, Neurosurgery \& Psychiatry, 76, 45-47. http://dx.doi.org/10.1136/jnnp.2004.060467

[30] Rodgers, R.J. and Johnson, N.J.T. (1995) Factor Analysis of Spatiotemporal and Ethological Measures in the Murine Elevated Plus-Maze Test of Anxiety. Pharmacology, Biochemistry and Behavior, 52, 297-303. http://dx.doi.org/10.1016/0091-3057(95)00138-M

[31] Pellow, S. and File, S.E. (1985) The Effects of Putative Anxiogenic Compounds (FG 7142, CGS 8216 and Ro 15-1788) on the Rat Corticosterone Response. Physiology and Behavior, 35, 587-590. http://dx.doi.org/10.1016/0031-9384(85)90145-3

[32] Treit, D. and Fundytus, M. (1988) Thigmotaxis as a Test for Anxiolytic Activity in Rats. Pharmacology, Biochemistry and Behavior, 31, 959-962. http://dx.doi.org/10.1016/0091-3057(88)90413-3

[33] Carobrez, A.P. and Bertoglio, L. (2005) Ethological and Temporal Analyses of Anxiety-Like Behavior: The Elevated Plus-Maze Model 20 Years on. Neuroscience and Biobehavioral Reviews, 29, 1193-1205. http://dx.doi.org/10.1016/j.neubiorev.2005.04.017

[34] Uzun, S., Kozumplik, O. and Jakovljević, M. (2010) P03-348 Agitation and Insomnia during Therapy with Alprazolam: Case Report. European Psychiatry, 25, 963. http://dx.doi.org/10.1016/S0924-9338(10)70954-8

[35] Izquierdo, I., Bevilaqua, L.R., Rossato, J.I., Bonini, J.S., Da Silva, W.C., Medina, J.H. and Cammarota, M. (2006) The Connection between the Hippocampal and the Striatal Memory Systems of the Brain: A Review of Recent Findings. Neurotoxicity Research, 10, 113-121. http://dx.doi.org/10.1007/BF03033240

[36] Cryan, J.F., Mombereau, C. and Vassout, A. (2005) The Tail Suspension Test as a Model for Assessing Antidepressant Activity: Review of Pharmacological and Genetic Studies in Mice. Neuroscience and Biobehavioral Reviews, 29, 571625. http://dx.doi.org/10.1016/j.neubiorev.2005.03.009

[37] Overstreet, D.H. (2012) Modeling Depression in Animal Models. Methods in Molecular Biology, 829, 125-144. http://dx.doi.org/10.1007/978-1-61779-458-2_7

[38] Schmauss, M. (2012) Fortschritte der Medizin. Vol. 19, 69-72.

[39] Baldessarini, R.J. (2001) Drugs and the Treatment of Psychiatry and Mania. In: Hardman, J.G. and Limbird, I.E., Eds., Goodman and Gilman, the Pharmacological Basis of Therapeutics, McGraw-Hill, New York, 175-191.

[40] Stone, J.M., Raffin, M., Morrison, P. and McGuire, P.K. (2010) The Biological Basis of Antipsychotic Response in Schizophrenia. Journal of Psychopharmacology, 24, 953-964. http://dx.doi.org/10.1177/0269881109106959

[41] Pereira, M., Siba, I.P., Chioca, L.R., Correia, D., Vital, M.A.B.F., Pizzolatti, M.G., Santos, A.R.S. and Andreatini, R. 
(2011) Myricitrin, a Nitric Oxide and Protein Kinase C Inhibitor, Exerts Antipsychotic-Like Effects in Animal Models. Progress in Neuro-Psychopharmacology and Biological Psychiatry, 35, 1636-1644. http://dx.doi.org/10.1016/j.pnpbp.2011.06.002

[42] Agid, O., Mamo, D., Ginovart, N., Vitcu, I., Wilson, A.A., Zipursky, R.B., et al. (2007) Striatal vs Extrastriatal Dopamine $\mathrm{D}_{2}$ Receptors in Antipsychotic Response: A Double-Blind PET Study in Schizophrenia. Neuropsychopharmacology, 32, 1209-1215. http://dx.doi.org/10.1038/sj.npp.1301242

[43] Porsolt, R.D., Moser, P.C. and Castagné, V. (2010) Behavioral Indices in Antipsychotic Drug Discovery. Journal of Pharmacology and Experimental Therapeutic, 333, 632-638. http://dx.doi.org/10.1124/jpet.110.166710 
Scientific Research Publishing (SCIRP) is one of the largest Open Access journal publishers. It is currently publishing more than 200 open access, online, peer-reviewed journals covering a wide range of academic disciplines. SCIRP serves the worldwide academic communities and contributes to the progress and application of science with its publication.

Other selected journals from SCIRP are listed as below. Submit your manuscript to us via either submit@scirp.org or Online Submission Portal.
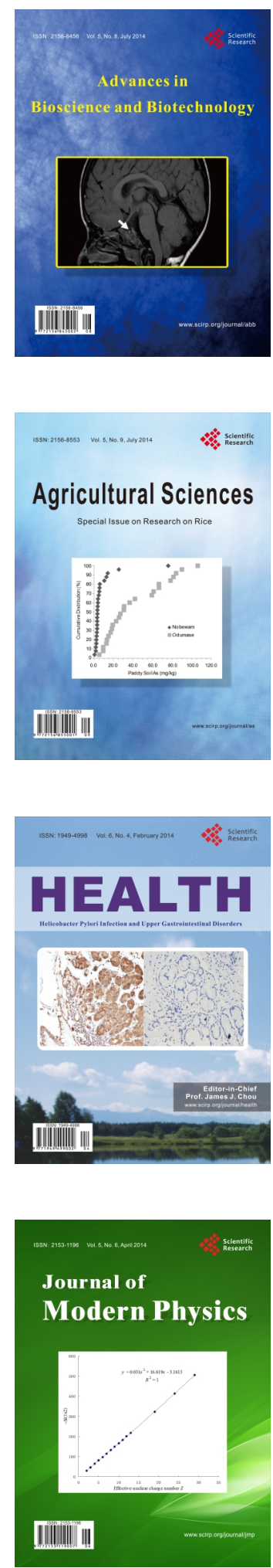
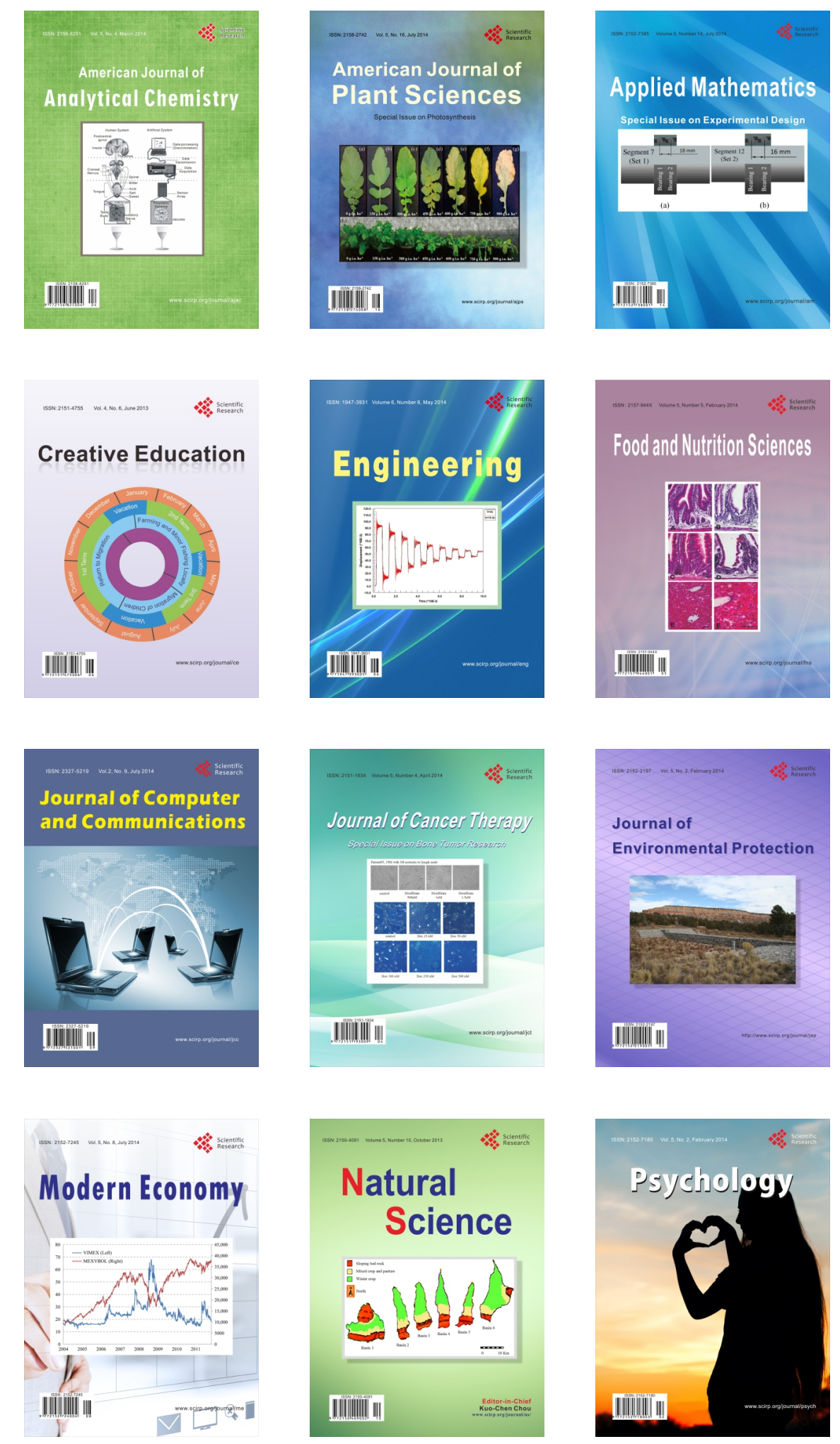